\title{
Constitutive production of angiotensin converting enzyme from rheumatoid nodule cells under serum free conditions
}

\author{
Makoto Goto, Minoru Sasano, Michio Fuzisawa, Tetsuro Okabe, Keiko Nishizawa
}

\begin{abstract}
Angiotensin converting enzyme was assayed in serum free culture supernatants from unstimulated rheumatoid nodule cells. Angiotensin converting enzyme was released spontaneously and the angiotensin converting enzyme derived from rheumatoid nodule cells was suppressed in a dose and time dependent manner by the protein synthesis inhibitor cycloheximide. These data suggest the constitutive de novo synthesis of angiotensin converting enzyme by rheumatoid nodule cells.
\end{abstract}

Rheumatoid arthritis (RA) is characterised by the formation of non-necrotising granulomas including pannus and subcutaneous nodules rich in monocyte lineage cells. There is evidence of monocyte lineage cell activation in patients with RA. For example, HLA-DR expression in rheumatoid synovial membrane macrophages is increased $^{1}$; and cloned synovial membrane cells, including macrophage-like cells, produce interleukin 1 and prostaglandin $E_{2}$ without stimulation in patients with RA. ${ }^{2}{ }^{3}$ The spontaneous release of interleukin $1 \beta$ and angiotensin converting enzyme, ${ }^{45}$ and enhanced phospholipase activity ${ }^{6}$ and $\mathrm{Fc}$ receptor activity ${ }^{7}$ in peripheral blood monocytes from patients with RA, have been described.

Rheumatoid subcutaneous nodules mainly consist of macrophage-like cells. ${ }^{8}$ In an earlier paper $^{8}$ we reported that rheumatoid nodule cells released interleukin $1 \beta$ and prostglandin $E_{2}$ spontaneously, in a similar manner to rheumatoid peripheral blood monocytes ${ }^{45}$ and synovial membrane cells. ${ }^{23}$ Experiments now in progress indicate the increased release of angiotensin converting enzyme and interleukin 1 from cloned cells in rheumatoid synovial membranes.

The increased angiotensin converting enzyme activity of monocytes and synovial cells from patients with RA raises the question of whether similar cell types distributed in inflammatory lesions such as rheumatoid nodules also release angiotensin converting enzyme, as do cells in sarcoidosis nodules. ${ }^{10}$

\section{Patients and methods}

PATIENTS

Studies were carried out on four female patients (aged about 27-58 years) with classical RA as defined by the American Rheumatism Association criteria. ${ }^{11}$ All subjects were seropositive for rheumatoid factor (RAHA 1/320-1/2560). They were treated with non-steroidal antiinflammatory drugs and small doses $(<5 \mathrm{mg} /$ day) of prednisolone.

ISOLATION OF RHEUMATOID NODULE CELLS Subcutaneous nodules were removed from the olecranon region while the patients were under local anaesthesia. The rheumatoid nodules were immediately minced with scissors, washed extensively, and plated into tissue culture plates in HAM F-10 medium (Gibco, Grand Island, NY, USA) supplemented with $10 \%$ endotoxin free fetal bovine serum (Gibco), $100 \mathrm{U} / \mathrm{ml}$ penicillin, $100 \mu \mathrm{g} / \mathrm{ml}$ streptomycin, and $10 \mathrm{mM}$ HEPES buffer (Sigma, St Louis, MO, USA). When cell outgrowths were observed during the culture period, the cells were collected and examined for the release of angiotensin converting enzyme as described in the following.

RELEASE OF ANGIOTENSIN CONVERTING ENZYME FROM RHEUMATOID NODULE CELLS

Cell outgrowths from rheumatoid nodules were collected and resuspended in culture medium. The cells were plated in 96 well tissue culture plates and cultured for several days. A monolayer of macrophage-like cells (about 5000 cells) was obtained and incubated for 24 hours in serum free medium. Cloned synovial fibroblast-like cells from patients with RA (about 5000 cells) and normal skin fibroblast-like cells (about 5000 cells) served as controls. In separate experiments, various concentrations (about $100 \mathrm{pg} / \mathrm{ml}$ to 100 $\mu \mathrm{g} / \mathrm{ml}$ ) of cycloheximide (Sigma) were added for 24 hours or the cells were cultured with 100 $\mathrm{ng} / \mathrm{ml}$ cycloheximide for up to 48 hours. The medium was collected and centrifuged to remove any suspended cells.

\section{MEASUREMENT OF ANGIOTENSIN CONVERTING} ENZYME ACTIVITY

Angiotensin converting enzyme activity was measured by the addition of angiotensin $I$ to the reaction mixture and measurement of the angiotensin II generated by radioimmunoassay. ${ }^{10}$ Bradykinin potentiating peptide $B$, angiotensin I, angiotensin II, and bestatin were purchased from Protein Research Foundation (Osaka, Japan). Angiotensin I and angiotensin II labelled with iodine-125 were obtained from New England Nuclear (Boston, MA, USA). Other reagents were of analytical-reagent grade and were obtained from commercial sources. 


\section{Results}

Table 1 shows that when the rheumatoid nodule cells were cultured in serum free HAM F-10 medium, angiotensin converting enzyme activity appeared spontaneously. The amount of angiotensin converting enzyme released from the rheumatoid nodule cells over 24 hours was about $20-40 \mathrm{pg} / 20 \mathrm{minutes} / \mathrm{well}$. Angiotensin converting enzyme activity could not be detected in the culture supernatants from cloned rheumatoid synovial fibroblast-like cells and normal skin fibroblasts. Table 2 shows that the angiotensin converting enzyme activity was inhibited in a dose dependent manner when the cells were cultured with $1 \mathrm{ng} / \mathrm{ml}$ to $100 \mu \mathrm{g} / \mathrm{ml}$ cycloheximide for 24 hours. Cycloheximide at a concentration of $100 \mu \mathrm{g} / \mathrm{ml}$ completely suppressed the angiotensin converting enzyme activity in the culture supernatant. When the cells were treated with $100 \mathrm{ng} / \mathrm{ml}$ cycloheximide for about $12-48$ hours in culture before assay, the angiotensin converting enzyme activity of rheumatoid nodule cells was suppressed in a time dependent manner (table 3).

Table 1 Angiotensin converting enzyme (ACE) activity in rheumatoid nodule cells.

\begin{tabular}{ll}
\hline Rheumatoid nodule cells & $\begin{array}{l}\text { ACE activity } \\
(p g / 20 \text { minutes/well/24 hours })\end{array}$ \\
\hline Patient No 1 & 40 \\
Patient No 2 & 36 \\
Patient No 3 & 20 \\
Patient No 4 & 20 \\
\hline Rheumatoid nodule cells (about 5000 cells/well) were cultured
\end{tabular}

for 24 hours in serum free HAM F-10 medium.

Table 2 Dose dependent suppression of rheumatoid nodule cell derived angiotensin converting enzyme (ACE) activity by cycloheximide.

\begin{tabular}{ll}
\hline $\begin{array}{l}\text { Concentration of } \\
\text { cycloheximide: }\end{array}$ & $\begin{array}{l}\text { ACE activity } \\
(p g / 20 \text { minutes/well/24 hours })\end{array}$ \\
\hline $100 \mu \mathrm{g} / \mathrm{ml}$ & 0 \\
$10 \mu \mathrm{gl} / \mathrm{ml}$ & 4 \\
$1 \mu \mathrm{ml}$ & 4 \\
$100 \mathrm{ng} / \mathrm{ml}$ & 4 \\
$10 \mathrm{ng} / \mathrm{ml}$ & 16 \\
$1 \mathrm{ng} / \mathrm{ml}$ & 32 \\
$100 \mathrm{pg} / \mathrm{ml}$ & 36 \\
$0 \mathrm{pg} / \mathrm{ml}$ & 36
\end{tabular}

Rheumatoid nodule cells (about 5000 cells/well) were cultured for 24 hours in the presence of cycloheximide at the concentrations indicated.

Table 3 Time dependent suppression of rheumatoid nodule cell derived angiotensin converting enzyme (ACE) activity by cycloheximide.

\begin{tabular}{ll}
\hline Culture duration" (hours) & $\begin{array}{l}\text { ACE activity } \\
(p g / 20 \text { minutes/well) }\end{array}$ \\
\hline 0 & 20 \\
12 & 16 \\
24 & 8 \\
48 & 0 \\
\hline${ }^{*}$ Rheumatoid nodule cells (about 5000 cells/well) were cultured \\
with $100 \mathrm{ng} / \mathrm{ml}$ of cycloheximide for the times indicated.
\end{tabular}

\section{Discussion}

The spontaneous production of angiotensin converting enzyme from rheumatoid nodule cells was observed in this experiment in a similar manner to the production of peripheral blood monocytes in RA. ${ }^{5}$ Rheumatoid nodule cells are heterogenous in nature; in a separate experiment, however, most of the rheumatoid nodule cells used were shown to be macrophagelike cells HLA-DR and CD14 positive, but negative for factor VIII. ${ }^{8}$

The experiment with cycloheximide, a protein synthesis inhibitor, indicated that angiotensin converting enzyme was synthesised in vitro and secreted rather than released from the previously processed protein stores. Therefore rheumatoid nodule derived macrophage-like cells are activated in vitro.

Macrophage-like cells in rheumatoid synovial cells produce interleukin $1 \beta$ and prostaglandin $\mathrm{E}_{2}$ in vitro without stimulation and are HLADR positive. ${ }^{3}$ Macrophages in rheumatoid synovial fluid are also activated.

These results suggest that rheumatoid monocyte lineage cells are activated even in in vitro culture. This is the first report of the spontaneous production and release of angiotensin converting enzyme from rheumatoid nodule cells.

This work was supported in part by research grants from the Ministry of Health and Welfare Japan. Pepstatin A was kindly provided by Dr T Aoyagi of the Institute of Microbial Chemistry, Tokyo, Japan.

1 Miyasaka N, Sato K, Goto M, et al. Augmented interleukin-1 production and HLA-DR expression in the synovium of rheumatoid arthritis-possible involvement of joint rheumatoid arthritis-possible involvemen

2 Goto M, Sasano M, Yamanaka H, et al. Spontaneous production of an interleukin-1-like factor by cloned production of an interleukin-1-like factor by cloned
rheumatoid synovial cells in long-term culture. $f$ Clin rheumatoid synovial cells

3 Sasano M, Goto M, Nishioka K. Production of prostaglandin $\mathrm{E}_{2}$ induced by histamine by cloned rheumatoid synovial cells. Ann Rheum Dis 1990; 49: 504-6.

4 Goto M, Sasano M, Miyamoto T, et al. Lack of association of HLA-DR4 with interleukin-1 beta secretion from peripheral blood monocytes in patients with rheumatoid arthritis. F Rheumatol 1989; 16: 1025-8.

5 Goto M, Fujisawa M, Yamada A, et al. Spontaneous release of angiotensin converting enzyme and interleukin $1 \beta$ from patients with rheumatoid arthritis under serum free conditions. Ann Rheum Dis 1990; 49: 172-6.

6 Bomalaski J S, Clark M A, Zurier R B. Enhanced phospholipase activity in peripheral blood monocytes from patients with rheumatoid arthritis. Arthritis Rheum 1986; 29: 312-8.

7 Katayama S, Chia D, Nasu H, et al. Increased Fc receptor activity in monocytes from patients with rheumatoid arthritis. F Immunol 1981; 127: 643-7.

8 Miyasaka N, Sato K, Yamamoto K, Goto M, Nishioka K. Immunological and immunohistochemical analysis of rheumatoid nodules. Ann Rheum Dis 1989; 48: 220-6.

9 Selverstein E, Pertshuk L P, Friedland J. Immunofluorescent localization of angiotensin converting enzyme in epithelioid and giant cells of sarcoidosis granulomas. Proc Natl Acad Sci USA 1979; 76: 6646-8.

10 Okabe $T$, Yamagata $K$, Fujisawa $M$, et al. Increased angiotensin-converting enzyme in peripheral blood monocytes from patients with sarcoidosis. F Clin Invest 1985; 75: $911-4$.

11 Ropes M W, Bennett G A, Cobb S, Jacox R, Jessar R A. 1958 revision of diagnostic criteria for rheumatoid arthritis. Bull Rheum Dis 1985; 9: 175-6.

12 Firestein G S, Zvaifler N J. Peripheral blood and synovial fluid monocyte activation in inflammatory arthritis. 1. A cytofluorographic study of monocyte differentiation
antigens and class II antigens and their regulation by $\gamma$-interferon. Arthritis Rheum 1987; 30: 857-63. 